\title{
Nasopharyngeal Cancer pT4 TNM Finding v7
}

National Cancer Institute

\section{Source}

National Cancer Institute. Nasopharyngeal Cancer pT 4 TNM Finding v7. NCI Thesaurus. Code C88970.

Nasopharyngeal cancer with intracranial extension and/or involvement of cranial nerves, hypopharynx, orbit, or with extension to the infratemporal fossa/masticator space. (from AJCC 7th Ed.) 